\title{
The role of top management commitment in enhancing competitive advantage: The mediating role of green innovation, supplier, and customer integration
}

\author{
Hotlan Siagian $^{\mathrm{a}}$, Zeplin Jiwa Husada Tarigan ${ }^{\mathrm{a}^{*}}$ and Sautma Ronni Basana ${ }^{\mathrm{a}}$
}

${ }^{a}$ Master Management,Petra Christian University, Jl. Siwalankerto 121-131, Surabaya, Indonesia

\section{A B S T R A C T}

\section{Article history:}

Received October 1, 2021

Received in revised format

October 25, 2021

Accepted December 62021

Available online

December 62021

Keywords:

Top management commitment

Supplier integration

Green innovation

Customer integration

Competitive advantage
Recently, environmental protection is emerging as global warming is becoming an increasing issue of concern worldwide. In addition, the world society has shifted its preference from the conventional product to the environmental-friendly product. But, on the contrary, the manufacturing industry management is still in doubt whether the green practices benefit the company, given that it requires a lot of capital investment and culture change. This study examines the impact of top management commitment on competitive advantage with the mediating role of supplier integration, customer integration, and green innovation. The data collection used a questionnaire designed with a five-point Likert scale to measure the objective opinion of the respondents against the item statement by choosing the predetermined measurement scale starting with 1: strongly disagree up to 5: strongly agree. Questionnaires were created in Google Form link and distributed to 600 respondents via email, WhatsApp groups, and Facebook. This survey received 285 responses (response rate $47.50 \%$ ) considered valid for further analysis. Furthermore, the data were analyzed using the partial least square (PLS) technique using SmartPLS software version 3.0. The result revealed that top management commitment directly influences supplier integration, green innovation, customer integration. Top management commitment did not directly affect competitive advantage. Instead, competitive advantages were affected by supplier integration, green innovation, and customer integration. Similarly, green innovation was supported by supplier integration and customer integration. In addition, top management commitment indirectly affects competitive advantage through supplier integration, green innovation, and customer integration. This result implies that top management commitment plays a vital role and has multiple effects in enhancing competitive advantage through establishing strategy and policies. This result provides a practical contribution on how the manufacturing companies could improve competitive advantage and at the same time concerns the environmental protection through green innovation. This study could also enrich and extend the acceptance of the recent research in the context of the manufacturing industry. Finally, this work has some limitations, particularly regarding the population and the variables involved. Further studies on the current topic are suggested to apply the variables such as digital and technology capability as these issues are currently in the growing stage. Future research is also suggested to cover a broader population such as the service and health industry.

\section{Introduction}

Today, there has been a growing global concern for environmental preservation and the adoption of a green approach in numerous areas, such as green innovation. The Paris Climate Change accord took effect last November 2016; concerns about green practices such as green innovation have emerged and become the global requirement for the company to go global as proof that they had implemented an environmental protection management system. The adoption of the green * Corresponding author E-mail address: zeplin@petra.ac.id (Z. J. H. Tarigan)

(C) 2022 Growing Science Ltd. All rights reserved. doi: $10.5267 /$ j.uscm.2021.12.003 
concept, also called friendly- environment concerns profound climate change worldwide. In addition, there has been a prerequisite that any company going to the global market should be committed to environmental protection by practicing the ISO standard on the environmental protection management system proved by ISO 14000 certification. This certification obligated the company to adopt the environmental protection system by adopting eco-product design and eco-process. The pressure from Global warming and Market requirements has also pushed the company to adopt the green concept of friendlyenvironment such as green innovation. Green innovation adoption has also been fuelled by government regulations, external stakeholder pressures, and cost savings. Many countries, such as Indonesia, pledged to reduce greenhouse gas emissions and have passed the Environmental Protection Law and Policy. However, the law's and policy's implementation has not gone as planned. Moreover, practitioners have different understandings on this issue, particularly in terms of the benefit for the company from this green adoption because it necessitates investment and new management philosophy, especially in manufacturing industries. At the same time, the scholarship has conducted various studies to define the green innovation concept and its impact on company performance and competitive advantage. As a result, a different definition of green innovation has also emerged. A bibliometric analysis study on green innovation has indicated the extended studies on the definition of green innovation, its antecedents, and its outcomes for the company's benefit (Albort-Morant et al., 2017). This study showed that extant studies have various definitions, its antecedent as the key driver of green innovation, and the outcome benefit for the company. But those definitions have a goal in common: green innovation is destined to develop or create a product or process that does not harm the environment. Looking at the antecedent key driver of the green innovation, (Albort-Morant et al., 2017) has summarized several antecedent variables such as green supply chain, customer pressure, information technology, and organization top management commitment. However, relatively little literature is concerned with the relationship of top management commitment as an antecedent of green innovation and competitive advantage as the outcome. On the outcome side of the green innovation, researchers indicated the outcome of green innovation such as financial performance, green environment performance, customer capital, and competitive advantage. Compared with other outcomes, competitive advantage is relatively fewer than others. Therefore, this study concerns extending the research regarding the top management commitment as the antecedent, and competitive advantage as the outcome. As a short review, studies undertaken so far have postulated that green innovation could help companies gain a competitive advantage and improve performance (Díaz-García et al., 2015). At the same time, many businesses are pursuing green innovation in response to government environmental policies and the international environmental paradigm (Chen et al., 2006). Furthermore, organizations that adopt green innovation would benefit from a higher price from customers (Yildiz Çankaya \& Sezen, 2018).

On the other hand, green innovation implementation requires other parties such as suppliers and customers, which enables and supports the implementation of green innovation. Green innovation adoption necessitates collaboration with suppliers to ensure that all raw material or components requirements comply with the green orientation (Tarigan et al., 2021b). Collaboration or integration with suppliers allows both parties to use the friendly-environmental raw material on the product and prevent any hazardous waste and high energy consumption during the production process. Supplier integration allows the organization and supplier to work together through information sharing and shared choices, allowing for green innovation adoption (Shou et al., 2018). Studies have also indicated that collaboration with suppliers necessitates a longterm agreement between top management and a clear commitment. According to (Lockström et al., 2010), senior management commitment is critical in maintaining supplier relationships. Green innovation also necessitates collaboration with demand-side or downstream supply-chain partners such as distributors and customers. Customer integration is defined as how a corporation engages with its customers to improve product specification and enable joint planning such as product design (Wong et al., 2011). Establishing a collaboration with its major customer could easily communicate the idea and the future product design. In addition, the customer could provide an insight to the company concerning the product specification expected by the customer. In addition, the dedication of top management is critical in building customer integration (Tarigan et al., 2020a). The above discussion has revealed that green innovation has emerged as a requirement today and in the future in the business environment and social life. However, green innovation requires a new policy within the organization and support from suppliers and customers. Besides new policies, resources allocation, a new procedure, and new technology or system are needed. Therefore, top management commitment is required to succeed in green innovation, supplier integration, and customer integration.

Based on the above discussion and the review of the sextant studies, this study observed that further empirical research is still required to enrich the previous studies focusing on the green innovation concerning the antecedent driver, which is top management commitment the outcome corresponding to the competitive advantage. For this purpose, his study creates a new model involving five constructs to examine the effect of top management commitment in enhancing the competitive advantage through the mediation of supplier integration, green innovation, and customer integration. The novelty of this study is the new model, which examines the relationship of top management commitment, green innovation, supplier integration, customer integration, and competitive advantage simultaneously. The findings of this study are expected to provide insights useful for the manager in enhancing the competitive edge while considering green environmental sustainability. This study, therefore, raised two main streams of research goals: examining the extended acceptance of the direct relationship between two constructs, examining the mediating role of the supplier integration, green innovation, and customer integration in the relationship between top management commitment and competitive advantage. 
The rest of the paper is organized as follows: Section 2 deals with the literature review and hypotheses development, while Section 3 discusses the methodology, explaining the population, sampling, and data analysis technique. The analysis and result are described in section 4, which deals with the statistical result to assess the measurement and inner model. Section 5 follows with the discussion, which interprets the result of the analysis. Finally, Section 6 deals with the conclusion withdrawal based on the outcome and discussion.

\section{Literature Review}

\subsection{Green innovation}

Previously, innovation was defined as generating value through improved efficiency, productivity, and performance. In contrast, green innovation creates value by paying attention to the environment as expected by customers, industries, and companies through product and process innovation (Albort-Morant et al., 2017) (Charmondusit et al., 2016). Green innovation could be performed physically through product improvement or non-physical innovation through process improvement using technology that improves efficiency, pollution prevention, waste recycling, environmentally friendly product design, environmentally friendly packaging, and environmental management (Chen et al., 2006). According to (Bhardwaj 2016); (Wong 2012), there are two dimensions of green innovation: green product innovation; and green process innovation. Green product innovation is achieved with innovative design ideas, producing new environmentally friendly products better than conventional innovation. Green innovation is driven by implementing environmental regulations to meet customers' expectations about ecological concerns (Bekk et al., 2015). Green process innovation is related to innovation in products and or processes that do not harm the environment in energy savings, prevention of environmental pollution, waste recycling, and not producing toxic materials (Chen et al., 2006). The level of implementation of environmental sustainability has become a necessity today. In addition to being regulated by every country, concern for environmental sustainability has also become part of customer demand for environmentally friendly products and processes. Among the various definitions, (Franceschini et al., 2016) defined green innovation as using new or upgraded processes, technologies, systems, and products to mitigate or eliminate harmful environmental effects. According to Xie et al. (2019), green innovation is divided into green process and green product innovation. The traditional approach to product development aims to maximize profit (Thomé \& Scavarda, 2015). Recent research shows that green innovation is oriented towards product and process innovation that does not damage the environment (Chen et al., 2006; Zhang et al., 2020). In some studies, green innovation is articulated as creating or improving processes, technologies, systems, and products to avoid negative environmental impacts with different approaches (Beise \& Rennings, 2005; Kemp \& Oltra, 2011; Rennings, 2000). In comparison, the latest research has evolved where the concept of green innovation is oriented to innovation with the latest technology with a wider scope. (Adams et al., 2016; Zhang et al., 2020) suggested the green innovation be defined as environmentally friendly system management in response to environmental regulations. Barbieri \& Santos, (2020) found that SMEs ' eco-friendly business model can contribute to green innovation via a life cycle assessment approach.

Green innovation from various studies provides the same fundamentals, applying the latest technologies in product development and processes for environmentally friendly and community-friendly practices. Green innovation reduces harmful substances resulting from the production process, and the use of the products produced (Amores-Salvadó et al., 2014; Dangelico \& Pujari, 2010a; Xie et al., 2019; Yin et al., 2018) has discovered the importance of a green innovation approach through the process and product innovation in a bibliometric study. Research by Chen et al. (2006) defines the green process as process innovation associated with energy saving, pollution prevention, waste recycling, and non-toxic waste. At the same time, product innovation is related to energy-efficient product innovation, pollution prevention, waste recycling, non-toxic products, or green product design. Green process innovation (Govindan et al., 2015) emphasizes linkfriendly production and logistic processes. Meanwhile, (Lopes Santos et al., 2019) emphasized process innovation as an effort to reduce emissions of gas, water waste, and solid materials. Furtherly, (Xie et al., 2019) highlight innovative products, including eco-designing, eco-packaging, and energy efficiency improvement (Amores-Salvadó et al., 2014). Similarly, (Kammerer 2009) defined green product innovation as reducing environmental impacts throughout the product life cycle (e.g., recyclable and biodegradable packaging after production). This study assesses the green process innovation using research by (Roh et al., 2021; Chen et al., 2006, Ekins 2010; Amores-Salvadó et al., 2014). There are four indicators: (GPR1) the company effectively reduces the emission of hazardous substances or waste, (GPR2) the company recycles waste and emission, and re-used it, (GPR3) the company reduces the consumption of water, electricity, coal, or oil, (GPR4) the company minimizes the use of raw materials. While green product innovation adopting research by (Chen et al., 2006; Ma et al., 2017; Xie et al., 2019) which consists of (GPD1), the products innovation reduces pollutants or hazardous materials within the production process (GPD3) the product innovation leads to the recycling of waste, water, and materials. (GPD4) The product innovation leads to a reduction in energy use within the production process.

\subsection{Top Management Commitment}

Top management commitment (TMC) is a term that describes how top management participates in and supports the company's strategy and operations. In this situation, senior management sets and communicates the company's vision and goals, involves and participates in the company's management, allocates resources and time to the company's management, 
empowers and encourages staff, and monitors operations to meet goals (Amoako-Gyampah et al., 2018; Caroline et al., 2016; Niehoff et al., 2016; Tzempelikos, 2015). Top management is also defined as a person or group of people who have the authority to supervise and control management, create vision and goals, develop rules and policies, allocate resources, and carry out initiatives (Lewis et al., 2007). The Operation Manager or higher, the Head of Quality and Engineering, and human resources are all part of the operational level of senior management. This study looks at five aspects of top management commitment: communicating the firm's vision and goals (TMC1), involving and participating in operations (TMC2), empowering employees (TMC3), allocating resources (TMC4), and monitoring the actions (TMC5).

\subsection{Supplier integration}

Close coordination and cooperation between the company and its suppliers exemplify supplier integration (Das et al., 2006; Flynn et al., 2010; Tarigan et al., 2021b). A long-term agreement or partnership via a contract, such as a vendor-managed inventory agreement, could be used to realize the type of integration (Wong et al., 2020). Supplier integration necessitates formal communication and information sharing between parties to achieve the same goal and strategy (Shou et al., 2018). Previous research has revealed that the measurement of supplier integration varies. In terms of information sharing (SI1), collaboration (SI2), collaborative decision making (SI3), and system interconnection (SI4), this study used five indicators (Flynn et al., 2010; Kim \& Lee, 2010; Shou et al., 2018).

\subsection{Customer integration}

Customer integration refers to the extent to which a corporation engages with its customers to improve visibility and enable joint planning (Wong et al., 2011; Wong et al., 2020). Customers can also submit feedback that is used to introduce new products and determine whether to limit or extend product diversity (Tarigan et al., 2021b). Furthermore, Esmaeilian et al. (2016) discuss emerging methods for collecting and storing customers' inputs based on "Big Data" and other IT tools to support decision-making. This study uses five indicators for customer integration (Wong et al., 2011) for customer integration: have a higher level of information sharing with the major customer about market information (CI1), share information to major customers through information technologies (CI2), have a higher degree of joint planning and forecasting with major customers to anticipate demand (CI3), Our customers provide information to us in the procurement and production processes (CI4), Our customers are involved in our product development processes (CI5).

\subsection{Competitive advantage}

Competitive advantage has several definitions in various scientific articles. Competitive advantage is a value creation strategy that has never existed, and competitors did not do it before (Singh et al., 2018a). Another definition states that competitive advantage is the ability to achieve at least financial advantage compared to competitors in the same business sector (Hili et al., 2017). According to Sigalas et al. (2013), the company gained the capability of competing by using internal forces to take advantage of external opportunities, illuminate threats, and fix internal weaknesses. Companies with various valuable resources, difficult to replicate and organizations that can increase the company's excellence (Barney \& Clark, 2007). The firm's performance depends on its capabilities to manage the unique resources (Singh et al., 2018b). These resources should change according to the firms' environmental factors and overall strategy (Akter et al., 2020; Schilke et al., 2017). Furthermore, another study indicated that competitive advantage is the ability of an organization to defend its position over the competitor, which is measured in the form of price/cost, quality, delivery, and flexibility (Li et al., 2006). In addition, Koufteros et al., (2005) describe a research framework for competitive capabilities and define the following five dimensions: competitive pricing, premium pricing, value-to-customer quality, dependable delivery, and product innovation. This study adopted the competitive advantage measurement by Li et al. (2006) that competitive advantage is assessed using five indicators: organization is capable of competing against a major competitor based on low price/cost (CAD1), the organization is capable of offering product quality and performance that creates higher value for customers (CAD2), the organization is capable of providing on-time the type and volume of product required by the customer(s) (CAD3), the organization is capable of introducing innovative new products and features in the marketplace (CAD4), an organization is capable of introducing new products to market faster than major competitors (CAD5).

\section{Hypotheses Development}

\subsection{Top management commitment and supplier integration}

When it comes to working with suppliers, top management engagement is essential. The company's leadership decides to engage with suppliers. Because suppliers and companies agree to long-term agreements, implementers cannot integrate with suppliers. Instead, management must do so. Furthermore, the study suggests that top management commitment influences green purchasing, necessitating collaboration with 239 electronic companies in China (Yen \& Yen, 2012). Green purchasing is one example of supplier-customer partnership. According to research conducted in China's automotive industry, senior management commitment is critical in sustaining positive relationships with suppliers (Lockström et al., 2010). According to a study conducted in Indonesia's manufacturing business, senior management commitment has a role in setting a purchasing 
strategy in partnership with suppliers (Tarigan et al., 2020a). Hypotheses based on the reasoning mentioned above can be expressed as follows:

\section{$\mathbf{H}_{1}$ : Top management commitment affects supplier integration.}

\subsection{Top management commitment and green innovation}

The implementation of green innovation requires policies from the top management because it requires investment and new business strategies of the company. A survey on certified 181 exporting manufacturing companies in Turkey found that top management commitment positively and significantly increases the green process innovation (Burki et al., 2019). Research conducted by El-Kassar \& Singh, (2017) in 215 respondents working in the Middle East and North Africa (MENA) region and Gulf-Cooperation Countries (GCC) shows that management commitment influences the implementation of green innovation. (Burki et al., 2019) researching 181 manufacturer-customer relationships in Turkey found that under management commitment is indispensable in the performance of green innovation in terms of process innovation. Another study at 59 3-star hotels in Surabaya, Indonesia, showed that top management commitment affects green performance, where green performance includes the implementation of green innovation in products and processes (Tarigan et al., 2020b). A USA study of 206 companies showed that top management commitment positively influences the implementation of green innovation in companies (Kitsis \& Chen, 2021). Research at automotive manufacturing companies in India shows that top management commitment increases the success of green products innovation. Based on the Porter Hypothesis, Hu et al. (2017) found that companies achieve results only by innovating products and processes with pressure from companies. In a similar vein, the emphasized that green innovation is triggered by institutional pushes and pulls while technological pushes can also manifest (Hu et al., 2017; Horbach et al., 2012; Horbach et al., 2012). Therefore, a firm can accomplish green innovation as an environmentally exceptional performance when it has proacted in response to environmental uncertainty and knowledge externalities. This argument leads to the first hypothesis:

\section{$\mathbf{H}_{2}$ : Top management commitment affects green innovation.}

Customer integration could be in customer relationship management, and senior management commitment encourages it (Wong et al., 2020). According to Rafiki et al. (2019), top management also supports customer relationship management. Furthermore, Ivandianto \& Tarigan (2020) discovered that top management commitment influences customer relationship management in an Indonesian manufacturing business. The following hypothesis is made based on the previous description.

\section{$\mathbf{H}_{3}$ : Top management commitment influences customer integration.}

\subsection{Top management commitment and competitive advantage}

Top management commitment has an essential role in determining company policy. The top management has a responsibility to assess the company's strategy and policies. Concerning the company's strategy, management also decided to allocate the resources needed by the company following the company's procedure and policies in running the business and facing competition (Tarigan et al., 2021b). Therefore, the commitment to peak management is crucial in increasing the competitive advantage of companies. The study conducted on 49 manufacturing companies in Indonesia showed that top management commitment is fundamental in determining the success of companies in building competitive advantage (Tarigan et al., 2020a). Therefore, top management commitment directly or indirectly can increase the competitive advantage of manufacturing companies. Another study states that strategic leadership has a significant impact in building a sustainable competitive advantage (Mahdi \& Almsafir, 2014). This research was conducted by surveying 44 private universities in Iraq. Based on the above research findings, the following hypothesis is determined:

\section{H4: Top management commitment affects competitive advantage.}

\subsection{Supplier integration and green innovation}

Studies conducted on 176 manufacturing companies in China showed that integration with suppliers is needed to apply green innovation in products and processes (Du et al., 2018). In addition, research by Wu (2013) in 211 companies in information technology concluded that integration with suppliers is essential in supporting green innovation in products and processes. Furthermore, based on the questionnaire data from manufacturing companies in three developed economic zones in China, the implementation of the green innovation requires internal cross-department integration and integration with external supply chain partners such as suppliers and customers (Sun \& Sun, 2021). Therefore, this argument proposes the fifth hypothesis:

\section{H5: Supplier integration affects green innovation.}


The study by Burki et al. (2019) on the exporting manufacturing companies suggested that customer cooperation positively affects green process innovation. Another survey by Du et al. (2018) also showed that customer integration supports the implementation of green innovation in a study of 176 manufacturing companies in China. Research in Taiwan on 211 companies manufacturing information technology concluded that integration with suppliers is essential in implementing green innovation in products and processes (Wu, 2013). The questionnaire data from manufacturing companies in three developed economic zones in China shows that the implementation of green innovation is in dire need of support from external parties such as suppliers and customers (Sun \& Sun, 2021). The above explanation formulated the following hypothesis:

\section{$\mathrm{H}_{6}$ : Customer integration affects green innovation.}

\subsection{Supplier integration and competitive advantage}

A study in the global sector industry shows that supplier integration, such as information sharing between buyers and sellers, allows companies to build competitive advantages such as more efficient processes in the competition (Vanpoucke et al., 2014). Research on 400 managers at manufacturing companies in Malaysia shows that supply chain integration among them is integration with suppliers has an impact on its competitive advantage (Sukati et al., 2012). Other studies show that integration with suppliers increases competitive advantage in better quality, delivery reliability, process flexibility, and customer service at 139 manufacturing companies in China (Feng et al., 2010). The suppliers help these companies to improve product quality, reduce product development costs, accelerate the NPD speed and offer valuable insights on the design of the new products. RBV and KBV also suggest supplier involvement can help a firm sustain its competitive advantage in many ways. First, supplier involvement strengthens the partnerships that help improve the quality of materials. Second, supplier involvement can provide value in cost management. A survey on 135 manufacturing companies domiciled in East Java, Indonesia, revealed that strategic partnership with suppliers followed by a proper purchasing strategy enhanced the firm performance (Tarigan \& Siagian, 2021). As purchasing spends more than $50 \%$ of the sales dollars, reducing cost through effective management of the cost of inputs to production has great potential (Carr \& Pearson, 2002). For example, a company urgently needed specific components in short supply, but it managed to obtain them from a company through its guanxi network. Guanxi relationships are viewed as more reliable than written contracts in China because historically, the unreliable Chinese legal system made it difficult to uphold agreements (Leung et al., 2005). Research by Tarigan et al. (2021a) concluded that supply chain integration, such as suppliers, will improve. The study was conducted on 456 practitioners in the manufacturing industry in Indonesia. The above arguments suggest the following hypotheses:

\section{$\mathbf{H}_{7}$ : Supplier integration affects competitive advantage.}

\subsection{Green innovation and competitive advantage}

A survey of 215 respondents working in the Middle East and North Africa (MENA) and Gulf-Cooperation Countries, GCC showed that green product and process innovation improved manufacturing companies' performance and competitive advantage (El-Kassar \& Singh, 2017). Another study by Sellittoa et al. (2020) on 245 furniture industrial companies located in Southern Brazil indicated that green innovation improved the company's competitive advantage. Concern for environmental impact produces unique products and creates international market opportunities, especially in markets that care about ecological sustainability and improves corporate performance and business turnover in the long term (Boehe \& Barin Cruz, 2010). The company will increase its competitive advantage through green innovation over its competitors (Lu et al., 2016; Sellitto et al., 2020). Innovation must create value that has an improved impact on productivity, higher margins, high profits, several values to stakeholders, higher market share, better company image, improved performance in the environmental aspect, and ultimately improve the competitiveness of the company (Bornschlegl et al., 2016; Chen et al., 2012; Tu \& $\mathrm{Wu}, 2021)$. Organizations are willing to divest on green innovation because it creates new markets and the advantage of competing with a new image as an environmentally friendly company (Chen et al., 2006; Wong, 2012). Furthermore, according to various studies, organizations that achieve green innovation would be able to demand a higher price from customers (Yildiz Çankaya \& Sezen, 2018), improve their corporate image (Chen, 2007), and obtain a competitive edge (Xie et al., 2019). Research on 388 manufacturing companies in the field of equipment in China shows that green innovation increases the competitiveness of equipment manufacturing (Zameer et al., 2020). Another study on 327 manufacturing firms of different industry sectors in Taiwan showed that green innovation affects the competitive advantage of manufacturing companies (Wang, 2019). A study in 219 chemical product manufacturers in Jordan showed that green product innovation increases the company's competitive advantage (Al-Abdallah \& Al-Salim, 2021). Furthermore, the study highlighted that both firms also started to adapt to an environmentally friendly regime through green production (Dangelico \& Pujari, 2010b). A research in the manufacturing industry in Indonesia suggested that innovation is becoming an essential strategy in sustaining the business performance (Siagian et al., 2021). In addition, Li \& Du, (2021) have verified the relationship between corporate profitability and green innovation combined with processes and products through data envelopment analysis (DEA). Based on this discussion, the second hypothesis is formulated: 
H8: Green innovation influences competitive advantage.

\subsection{Customer integration with a competitive advantage}

Similar research by Feng et al. (2010) in 139 manufacturing companies in China also shows that integration with customers impacts competitive advantages in better quality, reliable delivery, and better customer service. Impact of customer involvement on competitive advantage the customers' role in the products and services innovation, engineering design, and production of products and services is increasingly crucial and dynamic. In the dynamic environment, customers are suggested to be integrated into value creation for absorbing their knowledge to sustain competitive advantage (Füller \& Matzler, 2007). Customers are contributing to the process of marketing, consumption, and delivery of products and services (Dong et al., 2008). A study by Luteberget (2005) addresses the customer roles and found that customer involvement in improving the process flexibility and product quality. Fang et al. (2008) also address that customer involvement affects new product value creation by improving the effectiveness of the new product development process. This study was empirically tested by collecting primary data from 188 manufacturers across different industries. From what has been discussed above, we summarize the ideas as follows:

\section{H9: Customer integration affects competitive advantage.}

\section{Indirect hypothesis development}

In addition to the formulation of direct hypotheses, the study also proposed indirect hypotheses to test whether intervening variables play a role in mediating the direct relationship between two variables.

\subsection{The influence of top management commitment on competitive advantage through supplier integration}

The principle used to form indirect hypothesis is based on the causal relationship between two variables. Previously, top management commitment has been formulated directly affecting supplier integration following research (Lockström et al., 2010; Tarigan et al., 2020a; Yen \& Yen, 2012). Then, previous discussions have also formulated that supplier integration affects increasing competitive advantage (Feng et al., 2010; Sukati et al., 2012; Vanpoucke et al., 2014). Integration with suppliers requires a strong commitment from management since the relationship needs a relocation of the company resources, new policy, and strategy, which could only be realized with the agreement from top management of the organization. Furthermore, integration with suppliers will provide products to customers such as quality, cost, product diversity, and speed of delivery that ultimately the company has an advantage over competitors. Based on the logic and arguments above, it can be proposed the tenth hypothesis, namely:

\section{$\mathbf{H}_{10}$ : Top management commitment affects competitive advantage through supplier integration.}

\subsection{The relationship of top management commitment, green innovation, and competitive advantage}

Green innovation is an approach by manufacturing companies to provide products based on the customer's needs and, at the same time, take into account the rising green issues. The green issues are avoiding any harmful effect of the product usage or process on the environment. For example, the product development does not use the material resulting in hazardous or poisonous material. The process does not result in toxic waste, which harms the environment. Green innovation needs top management commitment since it changes the policy and allocation of resources, even the renewal of production capability such as upgrading technology. As has been advised above, the top management commitment determines the success of green innovation implementation (Burki et al., 2019; El-Kassar \& Singh, 2017; Tarigan et al., 2020b; Kitsis \& Chen, 2021; Hu et al., 2017).

Furthermore, green innovation has a positive impact on the competitive advantage. Green innovation implementation adopts green environmental issues either on product development or production. On the other side, the customer is currently demanding that the product and process of manufacturing satisfy the environmental protection regulation. Therefore, it implies that the manufacturing that meets the environment protection requirement will receive appreciation from the public and buy the product from the company. This premise is also supported by previous studies that green innovation improve the competitive advantage of the company (Boehe \& Barin Cruz, 2010; Bornschlegl et al., 2016; Chen et al., 2006; Chen et al., 2012; Tu \& Wu, 2021; Wong, 2012). Hence, based on the above argument, the following hypothesis is formulated.

H11: Top management commitment influences the competitive advantage through green innovation.

\subsection{The relationship of top management commitment, customer integration, and competitive advantage}

As discussed above, the previous studies concluded that top management commitment influences customer integration (Ivandianto \& Tarigan, 2020; Rafiki et al., 2019). On the other hand, customer integration affects and improves the competitive advantage as suggested by (Dong et al., 2008; Feng et al., 2010; Füller \& Matzler, 2007; Luteberget, 2005). The two relationships imply that top management commitment is essential in involving the customer in the design or production 
process, so the company product and production process comply with customer needs and wants. Furthermore, the customer will prefer the product designed and produced based on their criteria, and they will buy the company's product in the longterm horizon. Based on this argument and direct relationship as depicted above, this research formulates the following hypothesis

H12: Top management commitment enhances competitive advantage through supplier integration and green innovation.

Furthermore, top management has a role in setting the policies of the organization, such as the decision to intensify the involvement of the customer in providing feedback to the organization about the need and requirements of the customer. Previous researchers have revealed that top management commitment plays an essential role in directing the organization to involve the customer in the decision-making process (Ivandianto \& Tarigan, 2020; Rafiki et al., 2019). Moreover, customer integration influences the competitive advantage. The feedback from the customer is essential to tailor the design of the product satisfying the customer need as having been proved by various studies (Feng et al., 2010; Füller \& Matzler, 2007; Luteberget, 2005). Following the above argument and relationship, the hypothesis is determined.

\section{H13: Top management commitment indirectly improves competitive advantage through customer integration.}

As shown previously, top management commitment determines the level of customer involvement in implementing the process or product innovation, which hypothesizes that top management commitment influences customer integration (Ivandianto \& Tarigan, 2020; Rafiki et al., 2019). Furthermore, the involvement of the customer in product and process design will enable the organization to perform the green-based innovation (Burki et al., 2019; Du et al., 2018; Sun \& Sun, 2021; Wu, 2013). This relationship, in the end, will enhance the competitive advantage of the company as suggested by (Boehe \& Barin Cruz, 2010; Bornschlegl et al., 2016; Chen et al., 2012; El-Kassar \& Singh, 2017; Tu \& Wu, 2021). Based on these relationships, this research postulates the following hypothesis.

H14: Top management commitment improves the competitive advantage through the mediating role of customer integration and green innovation.

The research framework based on the above literature review and the relationship between constructs is depicted in Fig. 1.

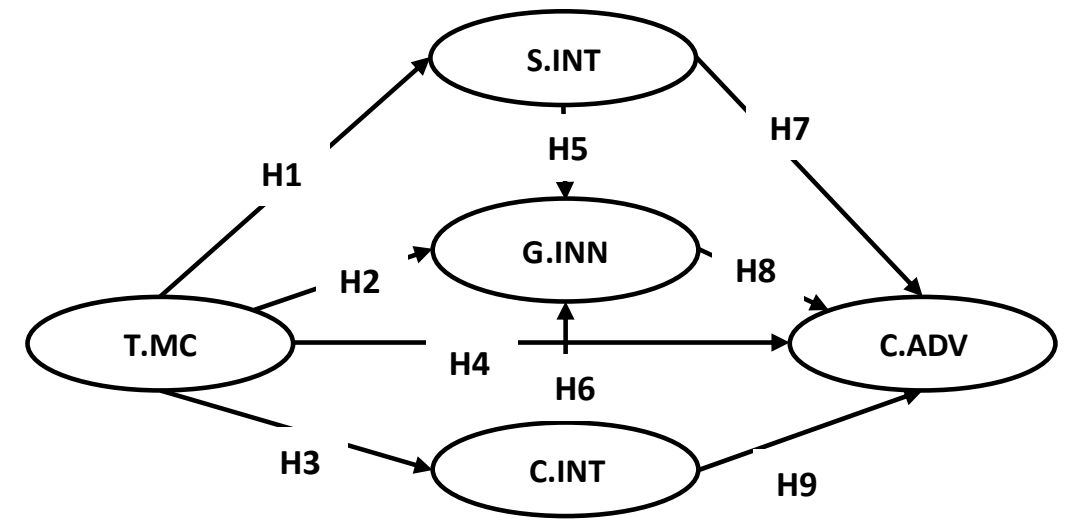

Note. T.MC: top management commitment, S.INT: Supplier integration, G.INN: green innovation, C.INT: customer integration, C.ADV: competitive advantage. The Figure did not indicate the indirect relationships (H10-H14)

Fig. 1. Research Framework and related hypotheses

\section{Methodology}

\subsection{Population and sample}

This research is a causal relationship with cross-sectional data design to examine the causal relationship between research variables. This study has surveyed 600 practitioners from March 2021 until August 2021 in various manufacturing companies around Indonesia. The data collection used a questionnaire designed to measure the objective opinion of the respondents against the item statement by choosing the predetermined measurement scale starting with 1: strongly disagree up to 5: strongly agree. Questionnaires were created in Google Form link and distributed to respondents via email, WhatsApp groups, and Facebook. This study received 305 from 600 respondents, and after validation against the completeness, respondent position, and industrial sector, 285 responses (response rate $47.50 \%$ ) were considered valid for further analysis. Furthermore, the data were analyzed using the partial least square (PLS) technique using SmartPLS software version 3.0. 


\subsection{Measurement Item}

As described in the Literature Review section, this study involves five constructs to create the research model addressing top management commitment, green innovation, supplier integration, customer integration, and competitive advantage. Each construct is assessed using predetermined items defined in the literature review section. There are 26 items used to measure those constructs with the following composition. Top management commitment is measured using five items, supplier integration with four items, green innovation with eight items, customer integration with four items, and competitive advantage with five items.

\section{Analysis Result}

\subsection{Descriptive analysis}

Based on the collected data, the respondent profile is presented in Table 1 in regards to the industry sector, experience, position, and function where the respondents are in charge.

Table 1

Respondent Profile

\begin{tabular}{|c|c|c|}
\hline Profile & Frequency & Percentage $(\%)$ \\
\hline \multicolumn{3}{|l|}{ Industry Sector } \\
\hline Basic and Chemical & 110 & $38.60 \%$ \\
\hline Food and Beverage & 62 & $21.75 \%$ \\
\hline Textile & 54 & $18.95 \%$ \\
\hline Automotive & 33 & $11.57 \%$ \\
\hline Home appliances & 26 & $9.13 \%$ \\
\hline \multicolumn{3}{|l|}{ Position } \\
\hline Director & 23 & $8 \%$ \\
\hline General Manager & 71 & $25 \%$ \\
\hline Manager & 137 & $48 \%$ \\
\hline Supervisor & 54 & $19 \%$ \\
\hline \multicolumn{3}{|l|}{ Experience } \\
\hline 1 to 2 years & 14 & $4.92 \%$ \\
\hline 3 to 5 years & 57 & $20 \%$ \\
\hline 6 to 8 years & 114 & $40 \%$ \\
\hline 9 to 10 years & 34 & $11.92 \%$ \\
\hline More than 10 years & 66 & $23,16 \%$ \\
\hline \multicolumn{3}{|c|}{ Function/Department } \\
\hline Purchasing & 66 & $23.16 \%$ \\
\hline Production & 110 & $38.59 \%$ \\
\hline Engineering & 27 & $9.47 \%$ \\
\hline Marketing & 52 & $18.25 \%$ \\
\hline R \& D & 31 & $10.53 \%$ \\
\hline
\end{tabular}

Respondents' origin is from various manufacturing sectors, which implies that respondents represent most of the manufacturing industry. In addition, the respondent's working experience indicated that all respondents have various working experiences from 1 up to more than 10 years. This finding showed that the respondents are eligible as they have more than enough experience and understand its decision-making, strategy, and operation. Besides, Table 1 also demonstrated the distribution of the function at which the respondent is in charge. All respondents are working on departments related to the research model, such as purchasing, production, marketing, engineering, and R \& D.

\subsection{Measurement Validity and Reliability}

The first step is to evaluate the measurement model to ensure that the indicators are valid and reliable. The value of each item's factor loadings is used to determine convergent validity, as shown in Table 1. When the factor loading value is more than 0.50 , the indicator is considered valid for convergent validity. Table 1 demonstrates that all indications are legitimate because all factor loading is greater than 0.50 . Besides, Table 1 demonstrated the mean score value and standard deviation of each indicator score. As described before, the indicator is measured using a five-point Likert scale, and the result indicated that all indicators score between 3.260 and 4.428. This result shows that all indicators scored between medium and high score values. The respondents perceived that the manufacturing companies in Indonesia are concerned about adopting the research construct to enhance the competitive advantage. The standard deviation value indicated how the respondent perception varies between respondents. In addition, Table 2 showed the standard deviation value between 0.661 and 1.124 . This result indicates that the respondents' perception varies between medium to high value. This finding proved that the manufacturing companies in Indonesia are not at a different level in adopting the research constructs in their business practices. Table 2 also lists the VIF value to assess the multicollinearity between indicators. The acceptance cut-off value is four, and the result in Table 2 showed that all values are less than four except for item GPD3 with a VIF value of 4.428 and GPR3 with a VIF value of 4.414. However, since the value is very close to four, these two items are considered acceptable. 
Table 2

Factor Loading, Mean, and Standard Deviation

\begin{tabular}{|c|c|c|c|c|}
\hline Construct/Item & Factor Loading & Item score (Mean) & Item reliability (SD) & VIF \\
\hline \multicolumn{5}{|c|}{ Top Management Commitment } \\
\hline TMC1 & 0.734 & 4.344 & 0.721 & 1.834 \\
\hline TMC2 & 0.870 & 4.453 & 0.661 & 2.634 \\
\hline TMC3 & 0.720 & 4.382 & 0.719 & 1.675 \\
\hline TMC4 & 0.819 & 4.396 & 0.740 & 2.084 \\
\hline TMC5 & 0.806 & 4.323 & 0.851 & 1.745 \\
\hline \multicolumn{5}{|l|}{ Green Innovation } \\
\hline GPD1 & 0.860 & 3.811 & 0.753 & 3.545 \\
\hline GPD2 & 0.848 & 3.740 & 0.796 & 3.752 \\
\hline GPD3 & 0.871 & 4.074 & 0.794 & 4.248 \\
\hline GPD4 & 0.785 & 4.011 & 0.866 & 2.782 \\
\hline GPR1 & 0.656 & 4.277 & 1.124 & 2.026 \\
\hline GPR2 & 0.729 & 4.253 & 1.027 & 2.105 \\
\hline GPR3 & 0.871 & 4.084 & 0.828 & 4.414 \\
\hline GPR4 & 0.797 & 4.193 & 0.908 & 2.913 \\
\hline \multicolumn{5}{|l|}{ Supplier Integration } \\
\hline SIP1 & 0.895 & 4.277 & 0.779 & 3.071 \\
\hline SIP2 & 0.844 & 4.253 & 0.758 & 2.455 \\
\hline SIP3 & 0.852 & 4.084 & 0.906 & 2.050 \\
\hline SIP4 & 0.767 & 4.193 & 0.755 & 1.551 \\
\hline \multicolumn{5}{|l|}{ Customer Integration } \\
\hline CIP1 & 0.735 & 3.884 & 0.990 & 1.498 \\
\hline CIP2 & 0.879 & 4.102 & 0.825 & 2.175 \\
\hline CIP3 & 0.609 & 4.088 & 0.912 & 1.249 \\
\hline CIP4 & 0.830 & 4.428 & 0.670 & 1.872 \\
\hline \multicolumn{5}{|l|}{ Competitive Advantage } \\
\hline CAD1 & 0.866 & 4.263 & 0.823 & 2.712 \\
\hline CAD2 & 0.817 & 4.056 & 0.881 & 2.080 \\
\hline CAD3 & 0.791 & 4.025 & 0.818 & 1.862 \\
\hline CAD4 & 0.712 & 4.168 & 0.874 & 1.623 \\
\hline CAD5 & 0.718 & 3.260 & 1.212 & 1.373 \\
\hline
\end{tabular}

The indicators are also examined against discriminant validity using the Forner and Larcker criterion, in addition to convergent validity. The indicator is considered valid when the square root of AVE for each indicator is greater than the correlation between the concepts (Fornell \& Larcker, 1981). Table 3 demonstrated the analysis result of the Forner-Larcker criterion and reliability as well in terms of Composite Reliability (C/R), Cronbach Alpha (C/A), Average variance evaluation (AVE). As shown, the square roots of AVE (written in bold) are greater than the correlation between constructs (not in bold), which implies that the discriminant validity of the indicators exists. Furthermore, the indicators for each construct are considered reliable when the value of $\mathrm{C} / \mathrm{R}, \mathrm{C} / \mathrm{A}$ exceeds 0.70 and exceeds 0.50 for AVE values. Based on Table 3 , the measurement indicators are all considered valid in terms of discriminant validity and reliability.

Table 3

Reliability and Forner-Larcker Criterion

\begin{tabular}{|c|c|c|c|c|c|c|c|c|}
\hline Construct & $\mathrm{C} / \mathrm{R}$ & $\mathrm{C} / \mathrm{A}$ & AVE & A & $\mathrm{B}$ & $\mathrm{C}$ & $\mathrm{D}$ & $\mathrm{E}$ \\
\hline Competitive advantage (A) & 0.887 & 0.841 & 0.613 & 0.783 & & & & \\
\hline Customer integration (B) & 0.851 & 0.765 & 0.593 & 0.548 & 0.770 & & & \\
\hline Green innovation (C) & 0.936 & 0.922 & 0.648 & 0.490 & 0.440 & 0.805 & & \\
\hline Supplier integration (D) & 0.906 & 0.861 & 0.706 & 0.540 & 0.660 & 0.426 & 0.840 & \\
\hline Top management commitment (E) & 0.893 & 0.853 & 0.627 & 0.375 & 0.504 & 0.393 & 0.459 & 0.792 \\
\hline
\end{tabular}

As the measurement model is considered valid and reliable, further analysis of the inner model can proceed. The next examination is to test the internal model with attention to explanatory power and predictive relevance. Explanatory power $\left(\mathrm{R}^{2}\right)$, which indicates the power of a variable independent, describes a dependent variable. The value of $\mathrm{R}^{2}$ is from 0 to 1 . The closer the value to 1 , the better the ability of the independent variable to explain the dependent variable. In addition, predictive relevance demonstrates the research model's ability to intercept the results of dependent variables. The value of predictive relevance ranges from 0 to 1 . A research model has predictive capabilities if the value of $\mathrm{Q}^{2}$ is greater than 0 .

Table 4

$\mathrm{R}^{2}$ and $\mathrm{Q}^{2}$ Result

\begin{tabular}{lcc}
\hline Construct & Explanatory Power $\left(\mathbf{R}^{2}\right)$ & Predictive Relevance $\left(\mathbf{Q}^{2}\right)$ \\
\hline Top management commitment & & 0.235 \\
Competitive advantage & 0.412 & 0.143 \\
Customer integration & 0.254 & 0.155 \\
Green innovation & 0.254 & 0.141 \\
Supplier integration & 0.211 & \\
\hline
\end{tabular}


Table 4 shows the R2 and Q2 where the Competitive advantage has $\mathrm{R}^{2}$ of 0.412 , which indicates the explanatory power medium level (range between $0.30-0.60$ ). At the same time, other constructs have $\mathrm{R}^{2}$ above 0.200 , which falls into the low category but is still acceptable. Furthermore, predictive relevance for each variable looks greater than 0 , so it can be concluded that the model has adequate predictive relevance.

The next analysis is the testing of direct and indirect hypotheses. Hypothesis testing looks at path coefficient values and $\mathrm{T}$ statistical values or P-value values. In this test, the hypothesis uses a significant level value of 5\% or a critical T value of 1.96 for two-way testing. The coefficient value itself indicates the strength of the causal effect between two variables and indicates the direction of the influence, whether negative or positive. Table 5 shows the analysis results, which reveal that 8 of the nine direct hypotheses are empirically supported with positive coefficient values, and statistical T values greater than 1.96 or $\mathrm{p}$ values less than 0.05 . The hypothesis that is not supported in this study is the $\mathrm{H} 4$ which indicated that top management commitment has no direct effect on competitive advantage in manufacturing companies domiciled in East Java, Indonesia.

Table 5

Path Coefficient, T-value, and P-Value

\begin{tabular}{|c|c|c|c|}
\hline Relationship & Path Coefficient & T Statistics & P Values \\
\hline (H1) Top management commitment $\rightarrow$ supplier integration & 0.459 & 6.593 & 0.000 \\
\hline (H2) Top management commitment $\rightarrow$ green innovation & 0.197 & 2.980 & 0.003 \\
\hline (H3) Top management commitment $\rightarrow$ customer integration & 0.504 & 7.487 & 0.000 \\
\hline (H4) Top management commitment $\rightarrow$ competitive advantage & 0.032 & 0.541 & 0.589 \\
\hline (H5) Supplier integration $\rightarrow$ green innovation & 0.197 & 2.164 & 0.030 \\
\hline (H6) Customer integration $\rightarrow$ green innovation & 0.210 & 2.312 & 0.021 \\
\hline (H7) Supplier integration $\rightarrow$ competitive advantage & 0.247 & 2.698 & 0.007 \\
\hline (H8) Green innovation $\rightarrow$ competitive advantage & 0.260 & 3.127 & 0.002 \\
\hline (H9) Customer integration $\rightarrow$ competitive advantage & 0.254 & 3.141 & 0.002 \\
\hline
\end{tabular}

In addition to direct hypotheses, the study also proposed five indirect hypotheses, and the result in Table 6 demonstrated that four of five indirect hypotheses were empirically supported, and one hypothesis (H12) is not supported.

Table 6

Indirect hypothesis result

\begin{tabular}{|c|c|c|c|}
\hline Indirect Relationship & Path Coeff. & T Statist. & P Values \\
\hline Top man. Commitment $\rightarrow$ supplier integration $\rightarrow$ competitive advantage (H10) & 0.113 & 2.719 & 0.007 \\
\hline Top man. commitment $\rightarrow$ green innovation $\rightarrow$ competitive advantage $(\mathrm{H} 11)$ & 0.051 & 2.191 & 0.028 \\
\hline Top man. Commitment $\rightarrow$ customer integration $\rightarrow$ competitive advantage (H12) & 0.128 & 2.903 & 0.004 \\
\hline Top man. Commitment $\rightarrow$ supplier integration $\rightarrow$ green innovation $\rightarrow$ competitive advantage (H13) & 0.024 & 1.597 & 0.110 \\
\hline Top man. commitment $\rightarrow$ customer integration $\rightarrow$ green innovation $\rightarrow$ competitive advantage (H14) & 0.028 & 2.071 & 0.038 \\
\hline
\end{tabular}

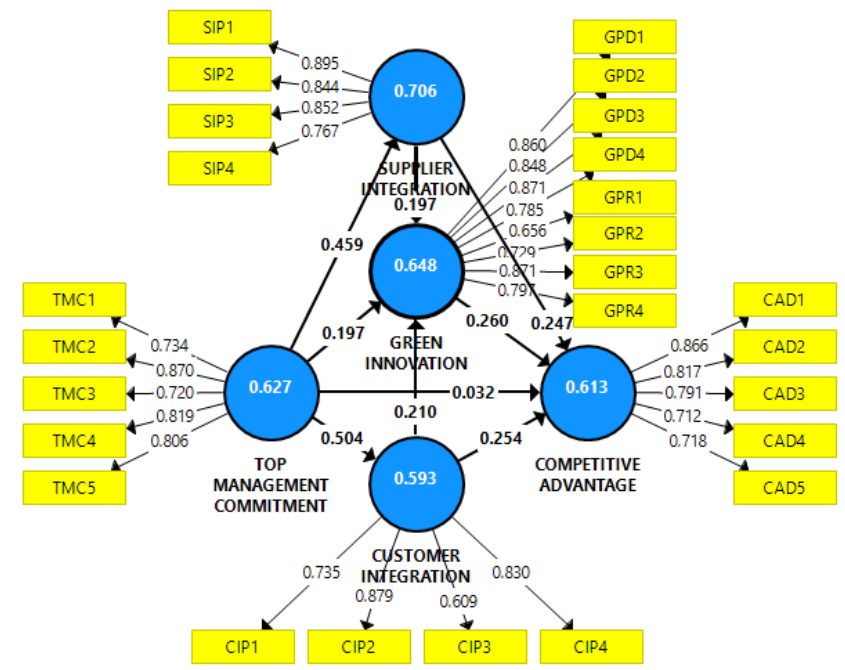

Note. 1 . The yellow-coloured box represents the indicator of the constructs. 2 . The number inside the circle is the AVE value. 3. The value on the line between indicator and construct is the factor loading. 4 . The value on the line between constructs is the path coefficient value.

Fig. 2. Research Model and Analysis Result 


\section{Discussion}

The first hypothesis (H1), top management commitment affects supplier integration in the manufacturing companies, is supported. Top management commitment, implemented by establishing policies, allocating resourcing, and empowering the employee, enables the organization to realize supplier integration in information sharing, collaboration in decision-making, and system interconnection between the organization and the supplier. This finding is aligned with various studies, which also suggested that top management commitment influences the success of integration with the supplier (Lockström et al., 2010; Tarigan et al., 2020a; Yen \& Yen, 2012). The second hypothesis (H2), top management influences green innovation, is empirically supported in the manufacturing industry. This result is in line with the studies by (Burki et al., 2019; Kitsis \& Chen, 2021; Hu et al., 2017; Horbach et al., 2012). Green innovation adoption requires a significant change of company policies. It changes the company strategy and needs substantial capital allocation to adopt green innovation. As shown before, green innovation is implemented in process innovation and product innovation. Regarding process innovation, the management is requested to adopt new technology, requiring the employee's unique skills. Hence, top management commitment is required in realizing green innovation. However, this research found that top management commitment did not improve the competitive advantage directly.

The third hypothesis (H3) was not supported in the manufacturing industry. Nevertheless, this finding is not an illogical result. The literature review defines top management commitment in policies, strategy, and communication establishment. At the same time, the competitive advantage is achieved through actions such as low price/cost advantage, high quality and value for customers, on-time delivery, better time to market, and new product introduction to the market. Hence, the top management commitment needs to be realized through green innovation, supplier, and customer integration. It implies that top management commitment could indirectly improve the competitive advantage through the mediation of supplier integration, green innovation, and customer integration. The fourth hypothesis (H4) testing indicated that top management commitment affects customer integration is supported. This finding shows that management plays an essential role in directing the organization to care for their customer. The customer could give excellent feedback for the organization in copying with the trending demand in the market. Therefore, the organization should place the customer's involvement as a top priority compared to other strategies. This finding reinforces the previous research on supply chain management (Ivandianto \& Tarigan, 2020; Rafiki et al., 2019).

Furthermore, the fifth hypothesis (H5) is that supplier integration enables green innovation. Green innovation requires material or components suitable for green innovation, either product innovation or process innovation. In the context of product innovation, organizations need material satisfying the green criteria such as reducing the emission of hazardous substances or waste, recycling waste, and reducing gas emission, re-usable product waste, and reducing energy use. The result of this study reinforces the previous research (Du et al., 2018; Sun \& Sun, 2021, Wu, 2013). In a similar sense, hypothesis H6 stating that customer integration influences the success of green innovation is accepted. This finding addresses the importance of feedback from a customer in dealing with green innovation. Green innovation should satisfy the customer's needs and wants. The input from customers plays a critical role in proceeding with the green innovation initiated by the company. This result is aligned with previous research (Burki et al., 2019; Sun \& Sun, 2021). Moreover, this research also supports the other hypotheses that supplier integration, green innovation, and customer integration enhance competitive advantage (H7, H8, H9). This finding reinforces previous research that the involvement of suppliers, customers' involvement is highly essential to enhance the competitive advantage. In addition, following the trending issue on environmental protection, green innovation provides an additional benefit in improving the company's competitive advantage.

Besides the direct effect on the competitive advantage, this study also examines the indirect relationship of top management commitment on the competitive advantage through the mediating role of supplier integration, green innovation, and customer integration. From five indirect hypotheses, four are supported while one is rejected. Indeed, top management commitment indirectly affects competitive advantage by realizing supplier integration, green innovation, and customer integration $(\mathrm{H} 10, \mathrm{H} 11, \mathrm{H} 12)$. The indirect hypothesis in this study implies that top management commitment has multiple effects in enhancing competitive advantage. The top management level has the authority to establish the company's direction in the future, such as deciding to involve the supplier, customer in their business mission and operation, and follow the trending market like environmental protection by adopting green innovation in terms of process and product innovation. In addition, the last two hypotheses proposed in this study (H13, H14) are essential, which revealed that top management commitment also indirectly influences the competitive advantage through supplier integration and green innovation (H13) and customer integration and green innovation (H14). These findings showed that top management commitment has multiple effects on competitive advantage. Management commitment is vital in establishing the company mission and objective, such as partnering with external parties and adopting the upgraded technology.

In summary, these research findings provide an insight that the manufacturing companies need to improve their competitive advantage, particularly in the current pandemic situation. Therefore, the management needs to re-evaluate their existing supplier and customer involvement in running their business. Based on the descriptive analysis, it is found that the supplier integration, and customer integration, on average, are high. Still, some of them are not so good at building 
relationships. Hence, this result could pave the way for the manager to enhance the competitive advantage in facing the competition while obeying the new standard working restriction. Moreover, this research result has extended the acceptance of various research findings in the manufacturing sector in Indonesia and the presence of the mediating role of supplier integration, customer integration, and green innovation.

\section{Conclusion}

The initial purpose of this study is to examine the impact of top management commitment on competitive advantage with the mediating role of supplier integration, customer integration, and green innovation. Based on the literature review, nine direct and five indirect relationships have been formulated to examine. Eight of nine direct hypotheses were supported. The result revealed that eight direct hypotheses were supported, while another one was not supported. Top management commitment directly influences supplier integration (H1), green innovation (H2), customer integration (H4). However, top management commitment did not support hypothesis H3 stating that top management commitment affects competitive advantage. Moreover, there are five indirect hypotheses developed, and four were supported, and one was not. Top management commitment indirectly influences competitive advantage through the mediating role of supplier integration (H10), green innovation (H11), customer integration (H12). Finally, the study also showed that top management commitment did not affect competitive advantage through supplier integration and green innovation (H13). Instead, top management commitment improves competitive advantage through customer integration and green innovation (H14). This result implies that top management commitment plays a vital role and has multiple effects in enhancing competitive advantage through establishing strategy and policies.

As discussed previously, this research provides a practical contribution on how manufacturing companies could improve competitive advantage and at the same time concerns environmental protection through green innovation. Hence, company management should collaborate with external partners, including suppliers and customers, which helps the company enhance the competitive advantage to outperform the competition. This study could also enrich and extend the acceptance of the current research in the context of the manufacturing industry. In addition, this study has revealed that supplier integration, green innovation, and customer integration play a vital role in improving the competitive advantage in the current competition and customer needs shifting toward green issues. However, this work has some limitations, particularly regarding the population and the variables involved. Further studies on the current topic are suggested to involve the variables such as digital and technology capability as these issues are currently in the growing stage. Future research is also suggested to cover a broader population such as the service industry.

Top management commitment directly influences supplier integration (H1), green innovation (H2), customer integration. Top management commitment did not directly affect competitive advantage. Instead, competitive advantages were affected by supplier integration, green innovation, and customer integration. Similarly, green innovation was supported by supplier integration and customer integration. In addition, top management commitment indirectly affects competitive advantage through supplier integration, green innovation, and customer integration. This result implies that top management commitment plays a vital role and has multiple effects in enhancing competitive advantage through establishing strategy and policies. This result provides a practical contribution on how the manufacturing companies could improve competitive advantage and at the same time concerns the environmental protection through green innovation. Hence, company management should collaborate with external partners, including suppliers and customers, which helps the company enhance the competitive advantage to outperform the competition. In addition, this study has revealed that supplier integration, green innovation, and customer integration play a vital role in improving the competitive advantage in the current competition. At the same time, the customer needs have shifted toward green concerns. This study could also enrich and extend the acceptance of the recent research in the context of the manufacturing industry. Finally, this work has some limitations, particularly regarding the population and the variables involved. Further studies on the current topic are suggested to apply the variables such as digital and technology capability as these issues are currently in the growing stage. Future research is also suggested to cover a broader population such as the service and health industry.

\section{References}

Adams, R., Jeanrenaud, S., Bessant, J., Denyer, D., \& Overy, P. (2016). Sustainability-oriented Innovation: A Systematic Review. International Journal of Management Reviews, 18(2), 180-205. https://doi.org/10.1111/IJMR.12068

Akter, S., Gunasekaran, A., Wamba, S. F., Babu, M. M., \& Hani, U. (2020). Reshaping competitive advantages with analytics capabilities in service systems. Technological Forecasting and Social Change, 159. https://doi.org/10.1016/J.TECHFORE.2020.120180

Al-Abdallah, G. M., \& Al-Salim, M. I. (2021). Green product innovation and competitive advantage: an empirical study of chemical industrial plants in Jordanian qualified industrial zones. Benchmarking: An International Journal. https://doi.org/10.1108/BIJ-03-2020-0095

Albort-Morant, G., Henseler, J., Leal-Millán, A., \& Cepeda-Carrión, G. (2017). Mapping the Field: A Bibliometric Analysis of Green Innovation. Sustainability 2017, Vol. 9, Page 1011, 9(6), 1011. https://doi.org/10.3390/SU9061011

Amoako-Gyampah, K., Meredith, J., \& Loyd, K. W. (2018). Using a Social Capital Lens to Identify the Mechanisms of Top 
Management Commitment: A Case Study of a Technology Project: Https://Doi.Org/10.1177/875697281804900106, 49(1), 79-95. https://doi.org/10.1177/875697281804900106

Amores-Salvadó, J., Castro, G. M. De, \& Navas-López, J. E. (2014). Green corporate image: moderating the connection between environmental product innovation and firm performance. Journal of Cleaner Production, 83, 356-365. https://doi.org/10.1016/J.JCLEPRO.2014.07.059

Barbieri, R., \& Santos, D. F. L. (2020). Sustainable business models and eco-innovation: A life cycle assessment. Journal of Cleaner Production, 266, 121954. https://doi.org/10.1016/J.JCLEPRO.2020.121954

Barney, J. B., \& Clark, D. N. (2007). Resource-based theory: creating and sustaining competitive advantage. 316. https://books.google.com/books/about/Resource_Based_Theory.html?id=pGYTDAAAQBAJ

Beise, M., \& Rennings, K. (2005). Lead markets and regulation: a framework for analyzing the international diffusion of environmental innovations. Ecological Economics, 52(1), 5-17. https://doi.org/10.1016/J.ECOLECON.2004.06.007

Bekk, M., Spörrle, M., Hedjasie, R., \& Kerschreiter, R. (2015). Greening the competitive advantage: antecedents and consequences of green brand equity. Quality \& Quantity 2015 50:4, 50(4), 1727-1746. https://doi.org/10.1007/S11135015-0232-Y

Bhardwaj, B. R. (2016). Role of green policy on sustainable supply chain management: A model for implementing corporate social responsibility (CSR). Benchmarking: An International Journal, 23(2), 456-468. https://doi.org/10.1108/BIJ-082013-0077

Boehe, D. M., \& Barin Cruz, L. (2010). Corporate Social Responsibility, Product Differentiation Strategy and Export Performance. Journal of Business Ethics 2010 91:2, 91(2), 325-346. https://doi.org/10.1007/S10551-010-0613-Z

Bornschlegl, M., Bregulla, M., \& Franke, J. (2016). Methods-Energy Measurement - An approach for sustainable energy planning of manufacturing technologies. Journal of Cleaner Production, 135, 644-656. https://doi.org/10.1016/J.JCLEPRO.2016.06.059

Burki, U., Ersoy, P., \& Najam, U. (2019). Top management, green innovations, and the mediating effect of customer cooperation in green supply chains. Sustainability (Switzerland), 11(4). https://doi.org/10.3390/SU11041031

Caroline, N., Harriet, K., \& Anne, N. (2016). Top management commitment for successful small and mediumenterprises(SMEs): A hoax or a reality? European Scientific Journal, ESJ, 12(4), 259-259. https://doi.org/10.19044/ESJ.2016.V12N4P259

Carr, A. S., \& Pearson, J. N. (2002). The impact of purchasing and supplier involvement on strategic purchasing and its impact on firm's performance. International Journal of Operations and Production Management, 22(9-10), 1032-1053. https://doi.org/10.1108/01443570210440528/FULL/PDF

Charmondusit, K., Gheewala, S. H., \& Mungcharoen, T. (2016). Green and sustainable innovation for cleaner production in the Asia-Pacific region. Journal of Cleaner Production, 134(Part B), $443-446$. https://doi.org/10.1016/J.JCLEPRO.2016.06.160

Chen, Y.-S., Lai, S.-B., \& Wen, C.-T. (2006). The Influence of Green Innovation Performance on Corporate Advantage in Taiwan. Journal of Business Ethics 2006 67:4, 67(4), 331-339. https://doi.org/10.1007/S10551-006-9025-5

Chen, Y. S., Chang, C. H., \& Wu, F. S. (2012). Origins of green innovations: the differences between proactive and reactive green innovations. Management Decision, 50(3), 368-398. https://doi.org/10.1108/00251741211216197

Dangelico, R. M., \& Pujari, D. (2010a). Mainstreaming Green Product Innovation: Why and How Companies Integrate Environmental Sustainability. Journal of Business Ethics 2010 95:3, 95(3), 471-486. https://doi.org/10.1007/S10551010-0434-0

Dangelico, R. M., \& Pujari, D. (2010b). Mainstreaming Green Product Innovation: Why and How Companies Integrate Environmental Sustainability. Journal of Business Ethics 2010 95:3, 95(3), 471-486. https://doi.org/10.1007/S10551010-0434-0

Das, A., Narasimhan, R., \& Talluri, S. (2006). Supplier integration-Finding an optimal configuration. Journal of Operations Management, 24(5), 563-582. https://doi.org/10.1016/J.JOM.2005.09.003

Díaz-García, C., González-Moreno, Á., \& Sáez-Martínez, F. J. (2015). Eco-innovation: insights from a literature review. Https://Doi.Org/10.1080/14479338.2015.1011060, 17(1), 6-23. https://doi.org/10.1080/14479338.2015.1011060

Dong, B., Evans, K. R., \& Zou, S. (2008). The effects of customer participation in co-created service recovery. Journal of the Academy of Marketing Science, 36(1), 123-137. https://doi.org/10.1007/S11747-007-0059-8

Du, L., Zhang, Z., \& Feng, T. (2018). Linking green customer and supplier integration with green innovation performance: The role of internal integration. Business Strategy and the Environment, 27(8), 1583-1595. https://doi.org/10.1002/BSE.2223

Ekins, P. (2010). Eco-innovation for environmental sustainability: concepts, progress and policies. International Economics and Economic Policy 2010 7:2, 7(2), 267-290. https://doi.org/10.1007/S10368-010-0162-Z

El-Kassar, A.-N., \& Singh, S. K. (2017). Green innovation and organizational performance: The influence of big data and the moderating role of management commitment and HR practices. Technological Forecasting \& Social Change. https://doi.org/10.1016/j.techfore.2017.12.016

Esmaeilian, B., Behdad, S., \& Wang, B. (2016). The evolution and future of manufacturing: A review. Journal of Manufacturing Systems, 39, 79-100. https://doi.org/10.1016/j.jmsy.2016.03.001

Fang, E., Palmatier, R. W., \& Evans, K. R. (2008). Influence of customer participation on creating and sharing of new product value. Journal of the Academy of Marketing Science, 36(3), 322-336. https://doi.org/10.1007/S11747-007-0082-9

Feng, T., Sun, L., \& Zhang, Y. (2010). The effects of customer and supplier involvement on competitive advantage: An 
empirical study in China. Industrial Marketing Management, $39(8), \quad 1384-1394$. https://doi.org/10.1016/J.INDMARMAN.2010.04.006

Flynn, B. B., Huo, B., \& Zhao, X. (2010). The impact of supply chain integration on performance: A contingency and configuration approach. Journal of Operations Management, 28(1), 58-71. https://doi.org/10.1016/j.jom.2009.06.001

Fornell, C., \& Larcker, D. F. (1981). Evaluating Structural Equation Models with Unobservable Variables and Measurement Error. Journal of Marketing Research, 18(1), 39. https://doi.org/10.2307/3151312

Franceschini, S., Faria, L. G. D., \& Jurowetzki, R. (2016). Unveiling scientific communities about sustainability and innovation. A bibliometric journey around sustainable terms. Journal of Cleaner Production, 127, $72-83$. https://doi.org/10.1016/J.JCLEPRO.2016.03.142

Füller, J., \& Matzler, K. (2007). Virtual product experience and customer participation-A chance for customer-centred, really new products. Technovation, 6-7(27), 378-387. https://doi.org/10.1016/J.TECHNOVATION.2006.09.005

Govindan, K., Diabat, A., \& Madan Shankar, K. (2015). Analyzing the drivers of green manufacturing with fuzzy approach. Journal of Cleaner Production, 96, 182-193. https://doi.org/10.1016/J.JCLEPRO.2014.02.054

Hili, P., Gani, M. U., Hamzah, N., \& Rahman, Z. (2017). Effect of Human Capital and Leadership on Institutions' Performance and Competitive Advantages. IRA-International Journal of Management \& Social Sciences, 07(3), 479488. https://doi.org/10.21013/jmss.v7.n3.p9

Horbach, J., Rammer, C., \& Rennings, K. (2012). Determinants of eco-innovations by type of environmental impact - The role of regulatory push/pull, technology push and market pull. Ecological Economics, 78, 112-122. https://doi.org/10.1016/J.ECOLECON.2012.04.005

Hu, D., Wang, Y., Huang, J., \& Huang, H. (2017). How do different innovation forms mediate the relationship between environmental regulation and performance? Journal of Cleaner Production, 161, 466-476. https://doi.org/10.1016/J.JCLEPRO.2017.05.152

Ivandianto, G., \& Tarigan, Z. J. H. (2020). The Influence of Management Commitment towards Business Performance through Supply Chain Management and Customer Relationship Management. Journal of International Business and Economics, 8(2), 10-22. https://doi.org/10.15640/jibe.v8n2a2

Kammerer, D. (2009). The effects of customer benefit and regulation on environmental product innovation.: Empirical evidence from appliance manufacturers in Germany. Ecological Economics, 68(8-9), 2285-2295. https://doi.org/10.1016/J.ECOLECON.2009.02.016

Kemp, R., \& Oltra, V. (2011). Research Insights and Challenges on Eco-Innovation Dynamics. Https://Doi.Org/10.1080/13662716.2011.562399, 18(3), 249-253. https://doi.org/10.1080/13662716.2011.562399

Kim, D., \& Lee, R. P. (2010). Systems Collaboration and Strategic Collaboration: Their Impacts on Supply Chain Responsiveness and Market Performance*. Decision Sciences, 41(4), 955-981. https://doi.org/10.1111/J.15405915.2010.00289.X

Kitsis, A. M., \& Chen, I. J. (2021). Do stakeholder pressures influence green supply chain Practices?Exploring the mediating role of top management commitment. Journal of Cleaner Production, $316,128258$. https://doi.org/10.1016/J.JCLEPRO.2021.128258

Koufteros, X., Vonderembse, M., \& Jayaram, J. (2005). Internal and External Integration for Product Development: The Contingency Effects of Uncertainty, Equivocality, and Platform Strategy. Decision Sciences, 36(1), 97-133. https://doi.org/10.1111/J.1540-5915.2005.00067.X

Leung, T. K. P., Lai, K. H., Chan, R. Y. K., \& Wong, Y. H. (2005). The roles of xinyong and guanxi in Chinese relationship marketing. European Journal of Marketing, 39(5-6), 528-559. https://doi.org/10.1108/03090560510590700/FULL/PDF

Lewis, W. G., Pun, K. F., \& Lalla, T. R. M. (2007). Measuring Top Management Commitment in SMEs: A Self-Assessment Scale. Asian Journal on Quality, 8(3), 35-45. https://doi.org/10.1108/15982688200700024/FULL/HTML

Li, J., \& Du, Y. X. (2021). Spatial effect of environmental regulation on green innovation efficiency: Evidence from prefectural-level cities in China. Journal of Cleaner Production, 286, 125032. https://doi.org/10.1016/J.JCLEPRO.2020.125032

Lockström, M., Schadel, J., Harrison, N., Moser, R., \& Malhotra, M. K. (2010). Antecedents to supplier integration in the automotive industry: A multiple-case study of foreign subsidiaries in China. Journal of Operations Management, 28(3), 240-256. https://doi.org/10.1016/J.JOM.2009.11.004

Lopes Santos, D. F., Valente Rezende, M. D., \& Cruz Basso, L. F. (2019). Eco-innovation and business performance in emerging and developed economies. Journal of Cleaner Production, $237, \quad 117674$ https://doi.org/10.1016/J.JCLEPRO.2019.117674

Lu, I.-Y., Kuo, T., Lin, T.-S., Tzeng, G.-H., \& Huang, S.-L. (2016). Multicriteria Decision Analysis to Develop Effective Sustainable Development Strategies for Enhancing Competitive Advantages: Case of the TFT-LCD Industry in Taiwan. Sustainability 2016, Vol. 8, Page 646, 8(7), 646. https://doi.org/10.3390/SU8070646

Luteberget, A. (2005). Customer involvement in new service development: how does customer involvement enhance new service success? https:/uia.brage.unit.no/uia-xmlui/handle/11250/137180

Ma, Y., Hou, G., \& Xin, B. (2017). Green Process Innovation and Innovation Benefit: The Mediating Effect of Firm Image. Sustainability 2017, Vol. 9, Page 1778, 9(10), 1778. https://doi.org/10.3390/SU9101778

Mahdi, O. R., \& Almsafir, M. K. (2014). The Role of Strategic Leadership in Building Sustainable Competitive Advantage in the Academic Environment. Procedia - Social and Behavioral Sciences, 129, $289-296$. https://doi.org/10.1016/J.SBSPRO.2014.03.679 
Niehoff, B. P., Enz, C. A., \& Grover, R. A. (2016). The Impact of Top-Management Actions on Employee Attitudes and Perceptions: Https://Doi.Org/10.1177/105960119001500307, 337-352. https://doi.org/10.1177/105960119001500307

Rafiki, A., Hidayat, S. E., \& Al Abdul Razzaq, D. (2019). CRM and organizational performance: A survey on telecommunication companies in Kuwait. International Journal of Organizational Analysis, 27(1), 187-205. https://doi.org/10.1108/IJOA-11-2017-1276

Rennings, K. (2000). Redefining innovation - eco-innovation research and the contribution from ecological economics. Ecological Economics, 32(2), 319-332. https://doi.org/10.1016/S0921-8009(99)00112-3

Roh, T., Lee, K., \& Yang, J. Y. (2021). How do intellectual property rights and government support drive a firm's green innovation? The mediating role of open innovation. Journal of Cleaner Production, 317(October 2020$), 128422$. https://doi.org/10.1016/j.jclepro.2021.128422

Schilke, O., Hu, S., \& Helfat, C. E. (2017). Quo Vadis, Dynamic Capabilities? A Content-Analytic Review of the Current State of Knowledge and Recommendations for Future Research. Https://Doi.Org/10.5465/Annals.2016.0014, 12(1), 390439. https://doi.org/10.5465/ANNALS.2016.0014

Sellitto, M. A., Camfield, C. G., \& Buzuku, S. (2020). Green innovation and competitive advantages in a furniture industrial cluster: A survey and structural model. Sustainable Production and Consumption, 23, 94-104. https://doi.org/10.1016/J.SPC.2020.04.007

Sellittoa, M. A., Camfielda, C. G., \& Buzuku, S. (2020). Green innovation and competitive advantages in a furniture industrial cluster: A survey and structural model | Elsevier Enhanced Reader. Sustainable Production and Consumption, 23(94104). https://doi.org/https://doi.org/10.1016/j.spc.2020.04.007

Shou, Y., Hu, W., Kang, M., Li, Y., \& Park, Y. W. (2018). Risk management and firm performance: the moderating role of supplier integration. Industrial Management and Data Systems, 118(7), 1327-1344. https://doi.org/10.1108/IMDS-092017-0427

Shuhong, L., Ragu-Nathan, B., Ragu-Nathan, T. S., \& Subba Rao, S. (2006). The impact of supply chain management practices on competitive advantage and organizational performance. In Omega (Vol. 34, Issue 2, pp. 107-124). https://doi.org/10.1016/j.omega.2004.08.002

Siagian, H., Tarigan, Z. J. H., \& Jie, F. (2021). Supply chain integration enables resilience, flexibility, and innovation to improve business performance in covid-19 era. Sustainability (Switzerland), 13(9), 1-19. https://doi.org/10.3390/su13094669

Sigalas, C., Pekka Economou, V., \& B. Georgopoulos, N. (2013). Developing a measure of competitive advantage. Journal of Strategy and Management, 6(4), 320-342. https://doi.org/10.1108/JSMA-03-2013-0015

Singh, V., Vaibhav, S., \& Sharma, S. K. (2018a). Using structural equation modelling to assess the sustainable competitive advantages provided by the low-cost carrier model: The case of Indian airlines. Journal of Indian Business Research, 13(1), 43-77. https://doi.org/10.1108/JIBR-12-2017-0260

Singh, V., Vaibhav, S., \& Sharma, S. K. (2018b). Using structural equation modelling to assess the sustainable competitive advantages provided by the low-cost carrier model: The case of Indian airlines. Journal of Indian Business Research, 13(1), 43-77. https://doi.org/10.1108/JIBR-12-2017-0260

Sukati, I., Hamid, A. A., Baharun, R., Alifiah, M., \& Anuar, M. A. (2012). Competitive advantage through supply chain responsiveness and supply chain integration. 1(7), 1-11.

Sun, Y., \& Sun, H. (2021). Green innovation strategy and ambidextrous green innovation: The mediating effects of green supply chain integration. Sustainability (Switzerland), 13(9). https://doi.org/10.3390/su13094876

Tarigan, Z. J. H., \& Siagian, H. (2021). The effects of strategic planning, purchasing strategy and strategic partnership on operational performance. Uncertain Supply Chain Management, 9(2), 363-372. https://doi.org/10.5267/j.uscm.2021.2.006

Tarigan, Z. J. H., Siagian, H., \& Jie, F. (2020a). The role of top management commitment to enhancing the competitive advantage through ERP integration and purchasing strategy. International Journal of Enterprise Information Systems, 16(1), 53-68. https://doi.org/10.4018/IJEIS.2020010103

Tarigan, Z. J. H., Mochtar, J., Basana, S.R., \& Jie, F. (2021b). The effect of competency management on organizational performance through supply chain integration and quality. Uncertain Supply Chain Management, 9(2), 283-294. doi: 10.5267/j.uscm.2021.3.004

Tarigan, Z. J. H., Siagian, H., \& Jie, F. (2021a). Impact of internal integration, supply chain partnership, supply chain agility, and supply chain resilience on sustainable advantage. Sustainability (Switzerland), 13(10). https://doi.org/10.3390/su13105460

Tarigan, Z. J. H., Tanuwijaya, N. C., \& Siagian, H. (2020b). Does Top Management Attentiveness Affect Green Performance through Green Purchasing and Supplier Collaboration? Academy of Strategic Management Journal, 19(4). https://www.abacademies.org/articles/does-top-management-attentiveness-affect-green-performance-through-greenpurchasing-and-supplier-collaboration-9529.html

Thomé, A. M. T., \& Scavarda, A. (2015). A systematic literature review of design-manufacturing integration for sustainable products. Chemical Engineering Transactions, 45, 691-696. https://doi.org/10.3303/CET1545116

Tu, Y., \& Wu, W. (2021). How does green innovation improve enterprises' competitive advantage? The role of organizational learning. Sustainable Production and Consumption, 26, 504-516. https://doi.org/10.1016/J.SPC.2020.12.031

Tzempelikos, N. (2015). Top management commitment and involvement and their link to key account management 
effectiveness. Journal of Business and Industrial Marketing, 30(1), 32-44. https://doi.org/10.1108/JBIM-12-20120238/FULL/HTML

Vanpoucke, E., Vereecke, A., \& Wetzels, M. (2014). Developing supplier integration capabilities for sustainable competitive advantage: A dynamic capabilities approach. Journal of Operations Management, 32(7-8), 446-461. https://doi.org/10.1016/J.JOM.2014.09.004

Wang, C. H. (2019). How organizational green culture influences green performance and competitive advantage: The mediating role of green innovation. Journal of Manufacturing Technology Management, 30(4), 666-683. https://doi.org/10.1108/JMTM-09-2018-0314

Wong, C. Y., Boon-Itt, S., \& Wong, C. W. Y. (2011). The contingency effects of environmental uncertainty on the relationship between supply chain integration and operational performance. Journal of Operations Management, 29(6), 604-615. https://doi.org/10.1016/J.JOM.2011.01.003

Wong, W.-P., Sinnandavar, C.M., Soh, K.-L., (2020) The relationship between supply environment, supply chain integration and operational performance: The role of business process in curbing opportunistic behaviour. International Journal of Production Economics, doi: https://doi.org/10.1016/j.ijpe.2020.107966.

Wong, S. K. S. (2012). The influence of green product competitiveness on the success of green product innovation: Empirical evidence from the Chinese electrical and electronics industry. European Journal of Innovation Management, 15(4), 468490. https://doi.org/10.1108/14601061211272385

$\mathrm{Wu}, \mathrm{G}$. C. (2013). The influence of green supply chain integration and environmental uncertainty on green innovation in Taiwan's IT industry. Supply Chain Management, 18(5), 539-552. https://doi.org/10.1108/SCM-06-2012-0201

Xie, X., Huo, J., \& Zou, H. (2019). Green process innovation, green product innovation, and corporate financial performance: A content analysis method. Journal of Business Research, 101, 697-706. https://doi.org/10.1016/J.JBUSRES.2019.01.010

Yen, Y. X., \& Yen, S. Y. (2012). Top-management's role in adopting green purchasing standards in high-tech industrial firms. Journal of Business Research, 65(7), 951-959. https://doi.org/10.1016/J.JBUSRES.2011.05.002

Yildiz Çankaya, S., \& Sezen, B. (2018). Effects of green supply chain management practices on sustainability performance. Journal of Manufacturing Technology Management, 30(1), 98-121. https://doi.org/10.1108/JMTM-03-2018-0099

Yin, J., Gong, L., \& Wang, S. (2018). Large-scale assessment of global green innovation research trends from 1981 to 2016 : A bibliometric study. Journal of Cleaner Production, 197, 827-841. https://doi.org/10.1016/J.JCLEPRO.2018.06.169

Zameer, H., Wang, Y., Yasmeen, H., \& Mubarak, S. (2020). Green innovation as a mediator in the impact of business analytics and environmental orientation on green competitive advantage. Management Decision, 71873064. https://doi.org/10.1108/MD-01-2020-0065

Zhang, Y., Sun, J., Yang, Z., \& Wang, Y. (2020). Critical success factors of green innovation: Technology, organization and environment readiness. Journal of Cleaner Production, 264, 121701. https://doi.org/10.1016/J.JCLEPRO.2020.121701 
(C) 2022 by the authors; licensee Growing Science, Canada. This is an open access article distributed under the terms and conditions of the Creative Commons Attribution (CCBY) license (http://creativecommons.org/licenses/by/4.0/). 